\title{
Influence of Zinc Sulphate on the Corrosion Resistance of L80 Alloy Immersed in Sea Water in the Absence and Presence of Sodium Potassium Tartrate and Trisodium Citrate
}

\author{
A. Grace Baby ${ }^{a}$, Susai Rajendran ${ }^{b, *}$, V. Johnsirani ${ }^{a}$ \\ and Abdulhameed Al-Hashem ${ }^{c}$ \\ ${ }^{a} P G$ Department of Chemistry, Sakthi College of Arts and Science for Women, \\ Oddanchatram-624 619, India \\ ${ }^{b}$ Corrosion Research Centre, Department of Chemistry, St Antony`s College of Arts \\ and Science for Women, Dindigul-624005, India \\ ${ }^{c}$ Senior Research Scientist, Petroleum Research Centre, Kuwait Institute \\ for Scientific Research, Kuwait
}

Received June 15, 2018; accepted August 20, 2020

\begin{abstract}
In cooling water systems, seawater can be used. L 80 can be used as a pipeline for carrying sea water. However, this alloy will undergo corrosion. Corrosion can be prevented by the addition of inhibitors such as sodium potassium tartrate (SPT), trisodium citrate (TSC) and zinc sulphate. Corrosion resistance of L 80 alloy in sea water, in the absence and presence of the above inhibitors, has been evaluated by polarization study and AC impedance spectra. It was observed that SPT and TSC show better inhibition efficiency in the presence of $\mathrm{Zn}{ }^{2+}$. Further, it was found that the SPT$\mathrm{Zn}$ system is better than the TSC-Zn system.
\end{abstract}

Keywords: corrosion inhibition, seawater, sodium potassium tartrate, trisodium citrate, polarization study, AC impedance spectra, L80 alloy.

\section{Introduction}

Seawater makes up the oceans and seas, covering more than 70 percent of Earth surface. Seawater is a complex mixture of 96.5 percent of water, 2.5 percent of salts, and smaller amounts of other substances, including dissolved inorganic and organic materials, particulates and a few atmospheric gases [1]. Almost anything can be found in seawater. This includes dissolved materials from Earth crust, as well as materials released from organisms. The most important components of seawater that influence life forms are salinity, temperature, dissolved gases (mostly oxygen and carbon dioxide) and nutrients [2].

\footnotetext{
* Corresponding author. E-mail address: susairajendran@gamil.com
} 
Seawater can be used in cooling water systems, especially in ships and in marine environments. In these systems, L 80 alloy can be used to carry out seawater. Hence, knowledge of corrosion resistance of L80 alloy in seawater, in the presence of inhibitors, will be useful. Corrosion resistance of aluminium and its alloys [3, 4], zinc and its alloys [5, 6], copper and its alloys [7, 8], mild steel [9, $10]$, stainless steel [11, 12], nickel and its alloys [13, 14] in seawater has been evaluated. Corrosion inhibitors such as inorganic compounds $[15,16]$ and natural products $[17,18]$ have been used to prevent the corrosion of metals and alloys. In the present study, corrosion resistance of L 80 alloy in seawater, in the presence of sodium potassium tartrate (SPT) and trisodium citrate (TSC), has been evaluated by electrochemical studies, such as polarization study and AC impedance spectra. Influence of $\mathrm{Zn}^{2+}$ on the corrosion resistance of the above systems has also been evaluated.

\section{Experimental}

\section{Electrochemical studies}

In the present work, corrosion resistance of L 80 alloy immersed in various test solutions was measured by Polarization study and AC impedance spectra.

\section{Polarization study}

In the present study, polarization studies were carried out in a CHI Electrochemical work station/ analyzer, 660A model. It was provided with an automatic IR compensation facility. A three electrode cell assembly was used, as shown in Fig. 1.

The working electrode was L 80 alloy. SCE was the reference electrode. Platinum was the counter electrode. A time interval of 5 to 10 min was given for the system to attain a steady state open circuit potential. The working electrode and the platinum electrode were immersed in sea water, in the absence and presence of the inhibitor. Saturated calomel electrode was connected with the test solution through a salt bridge. From the polarization study, corrosion parameters, such as corrosion potential $\left(\mathrm{E}_{\mathrm{corr}}\right)$, corrosion current $\left(\mathrm{I}_{\mathrm{corr}}\right)$, Tafel slopes anodic $=$ $b_{a}$ and cathodic $=b_{c}$ and LPR (linear polarization resistance) values, were considered. The scan rate (V/S) was 0.01 . Hold time at (Efcs) was zero and quiet time (s) was two.

\section{AC impedance spectra}

In the present investigation, the same instrument and set-up used for the polarization study was used to record AC impedance spectra. A time interval of 5 to 10 min was given for the system to attain a steady state open circuit potential. The real part (Z') and imaginary part (Z') of the cell impedance were measured in ohms at various frequencies. AC impedance spectra were recorded with initial $\mathrm{E}(\mathrm{v})=0$, high frequency $(\mathrm{Hz}=1 \times 105)$, low frequency $(\mathrm{Hz}=1)$, amplitude $(\mathrm{V})$ $=0.005$ and quiet time $(\mathrm{s})=2$. From Nyquist plot, the values of charge transfer resistance $\left(\mathrm{R}_{\mathrm{t}}\right)$ and double layer capacitance $\left(\mathrm{C}_{\mathrm{dl}}\right)$ were calculated. 


$$
R t=(R s+R t)-R s
$$

where Rs = solution resistance.

$\mathrm{C}_{\mathrm{dl}}$ values were calculated using the relationship:

$$
\mathrm{Cdl}=\frac{1}{2 \times 3.14 \times \mathrm{Rt} \times \mathrm{f}_{\text {max }}}
$$

where $\mathrm{f}_{\max }=$ frequency at maximum imaginary impedance.

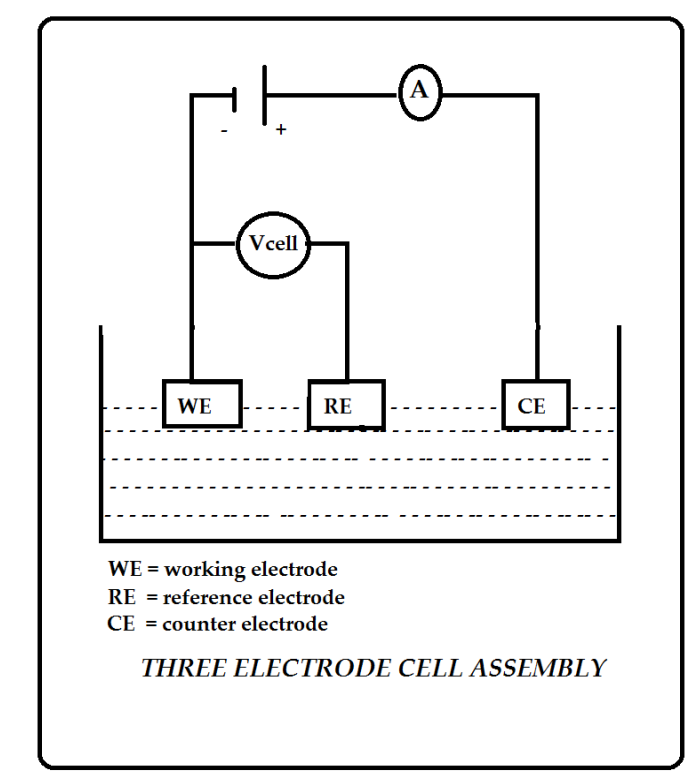

Figure 1. Three electrode cell assembly.

\section{Sea water}

The composition of sea water used in this study is given in Table 1. Sea water was collected in the Bay of Bengal, located at Kanampadi, East Coast Road, Chennai, India.

\section{L80 alloy}

L80 alloy was manufactured according to 5CT API specification. This is a controlled yield strength material with a hardness testing requirement.

L80 is usually used in wells with sour (hydrogen sulfide) environments. Chemical composition of L80 alloy is given in Table 2.

The remaining $\mathrm{Wt} \%$ was iron.

\section{Used inhibitors}

Pure samples of Sodium Potassium Tartrate (SPT), Tri Sodium Citrate (TSC) and Zinc Sulphate were used as corrosion inhibitors. 
Table 1. Composition of sea water.

\begin{tabular}{|c|c|c|c|}
\hline Physical examination & $\begin{array}{l}\text { Acceptable } \\
\text { limit }\end{array}$ & Permissible limit & Sample value \\
\hline Colour & & & $\begin{array}{l}\text { Colourless and } \\
\text { clear }\end{array}$ \\
\hline Odour & \multicolumn{2}{|c|}{ Unobjectionable } & Unobjectionable \\
\hline Turbidity NT units & 1 & 5 & 0.2 \\
\hline $\begin{array}{lll}\text { Total } & \text { dissolved } & \text { solids } \\
\mathrm{mg} / 1 & & \end{array}$ & 500 & 2000 & 29400 \\
\hline $\begin{array}{l}\text { Electrical conductivity } \\
\text { micro } \mathrm{mho} / \mathrm{cm}\end{array}$ & & & 42000 \\
\hline \multicolumn{4}{|l|}{ Chemical examination } \\
\hline $\mathrm{pH}$ & $6.5-8.5$ & $6.5-8.5$ & 7.46 \\
\hline pH Alkalinity as $\mathrm{CaCO}_{3}$ & & 0 & 0 \\
\hline Total Alkalinity as $\mathrm{CaCO}_{3}$ & 200 & 600 & 140 \\
\hline Total Hardness as $\mathrm{CaCO}_{3}$ & 200 & 600 & 4000 \\
\hline Calcium as ca & 75 & 200 & 1200 \\
\hline Magnesium as Mg & 30 & 100 & 240 \\
\hline Iron as $\mathrm{Fe}$ & 0.1 & 1 & 0 \\
\hline Magnesium as Mg & 0.1 & 0.3 & NT \\
\hline Free Ammonia as $\mathrm{NH}_{3}$ & 0.5 & 0.5 & 0.48 \\
\hline Nitrite as $\mathrm{NO}_{2}$ & 0.5 & 0.5 & 0.104 \\
\hline Nitrate as $\mathrm{NO}_{3}$ & 45 & 45 & 25 \\
\hline Chloride as $\mathrm{Cl}$ & 250 & 1000 & 15000 \\
\hline Fluoride as F & 1 & 1.5 & 1.8 \\
\hline Sulphate as $\mathrm{SO}_{4}$ & 200 & 400 & 1170 \\
\hline Phosphate as $\mathrm{PO}_{4}$ & 0.5 & 0.5 & 1.47 \\
\hline Tids Test 4 hrs as $\mathrm{O}_{2}$ & & & NT \\
\hline
\end{tabular}

Table 2. Chemical composition of L80 alloy.

\begin{tabular}{|l|c|c|c|c|c|c|c|c|c|c|c|c|c|}
\hline & $\mathbf{C}$ & $\mathbf{M n}$ & $\mathbf{M o}$ & $\mathbf{C r}$ & $\mathbf{N i}$ & $\mathbf{C u}$ & $\mathbf{T i}$ & $\mathbf{P}$ & & $\mathbf{S}$ & $\mathbf{S i}$ & $\mathbf{V}$ & $\mathbf{A l}$ \\
\hline Min & - & - & - & - & - & - & - & - & & - & - & - & - \\
\hline Max & 0.430 & 1.900 & - & - & 0.250 & 0.350 & - & 0.030 & & 0.030 & 0.450 & - & - \\
\hline
\end{tabular}

\section{Results and discussion}

\section{Electrochemical studies}

In the present work, corrosion resistance of L80 alloy immersed in various test solutions was measured by polarization study and AC impedance spectra.

\section{L80 alloy -sodiumpotassium tartrate (SPT) system}

\section{Polarization study}

It is seen from Table 3 that when SPT is added to sea water, the corrosion resistance of L80 alloy increases. This is revealed by the fact that when SPT is added to sea water, LPR values increases and $I_{\text {corr }}$ value decreases, as shown in Figs. 2 to 5. 
Table 3. Corrosion parameters of L80 alloy immersed in sea water, in the absence and presence of SPT and Zinc sulphate $\left(\mathrm{ZnSO}_{4} \cdot 7 \mathrm{H}_{2} \mathrm{O}\right)$, obtained by polarization study.

\begin{tabular}{|l|c|c|c|c|c|}
\hline System & $\begin{array}{c}\text { Ecorr } \\
\mathbf{m V ~ S C E}\end{array}$ & $\begin{array}{c}\mathbf{b}_{\mathbf{c}} \\
\mathbf{m V / d e c a d e}\end{array}$ & $\begin{array}{c}\mathbf{b}_{\mathbf{a}} \\
\mathbf{m V / d e c a d e}\end{array}$ & $\begin{array}{c}\text { LPR } \\
\text { Ohm } \mathbf{~ m}^{2}\end{array}$ & $\begin{array}{c}\mathbf{I}_{\mathbf{c o r r}} \\
\mathbf{A} / \mathbf{c m}^{2}\end{array}$ \\
\hline Sea water & -830 & 161 & 221 & 355 & $1.138 \times 10^{-4}$ \\
\hline $\begin{array}{l}\text { Sea water + SPT (300 } \\
\text { ppm) }\end{array}$ & -822 & 119 & 212 & 677 & $4.908 \times 10^{-5}$ \\
\hline $\begin{array}{l}\text { Sea water + SPT (300 } \\
\text { ppm) +ZnSO } 4 \text { (100 ppm) }\end{array}$ & -537 & 209 & 252 & 23882026 & $2.079 \times 10^{-9}$ \\
\hline
\end{tabular}

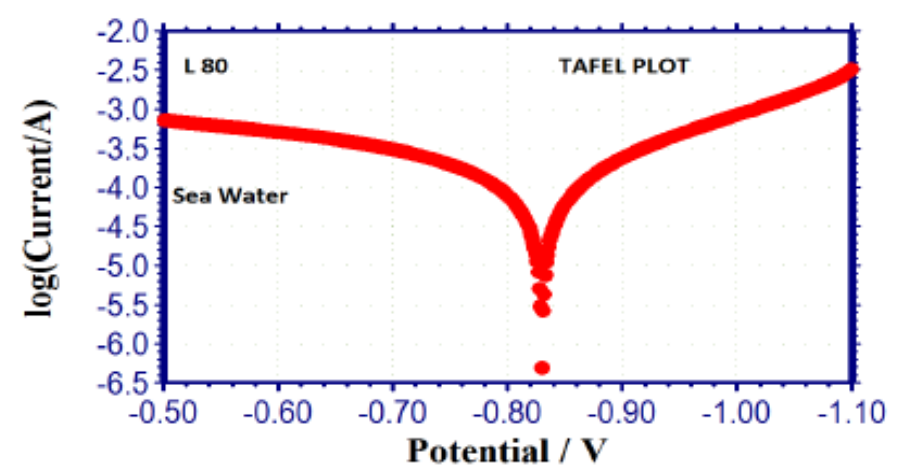

Figure 2. Polarization curve of L80 alloy immersed in sea water.

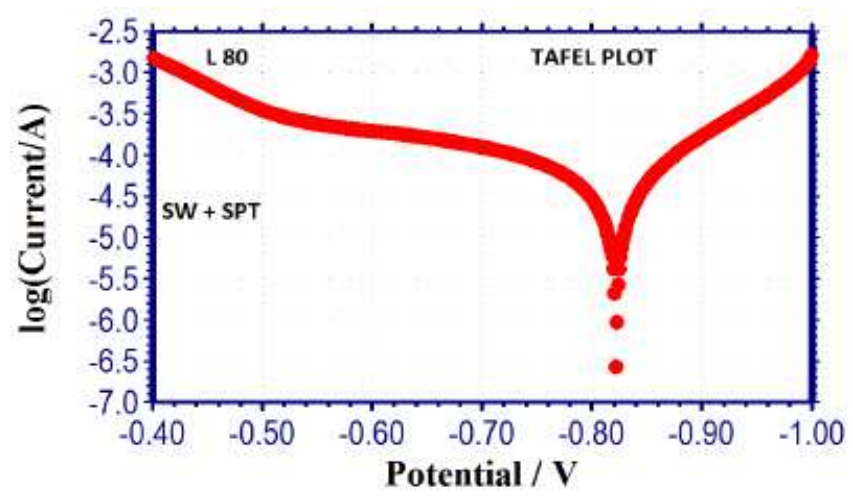

Figure 3. Polarization curve of L80 alloy immersed in sea water + SPT.

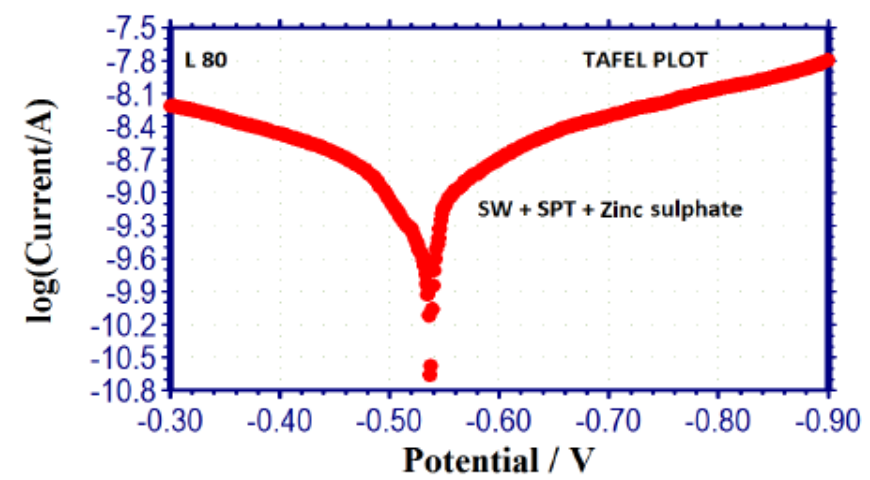

Figure 4. Polarization curve of L80 alloy immersed in sea water + SPT + zinc sulphate.

Influence of Zinc sulphate $\left(\mathrm{ZnSO}_{4} .7 \mathrm{H}_{2} \mathrm{O}\right)$

When $\mathrm{ZnSO}_{4} .7 \mathrm{H}_{2} \mathrm{O}$ was added to the above system, LPR value increased to a great extent (Fig. 5) and $\mathrm{I}_{\text {corr }}$ decreased considerably. This indicates that, in the 
presence of SPT - $\mathrm{ZnSO}_{4} .7 \mathrm{H}_{2} \mathrm{O}$ system, the corrosion resistance of $\mathrm{L} 80$ alloy in sea water increases to a great extent. A protective film is formed on the metal surface. This prevents transfer of electrons from anodic site to cathodic site. Hence, LPR value increases, which results in a decrease in the corrosion current value.

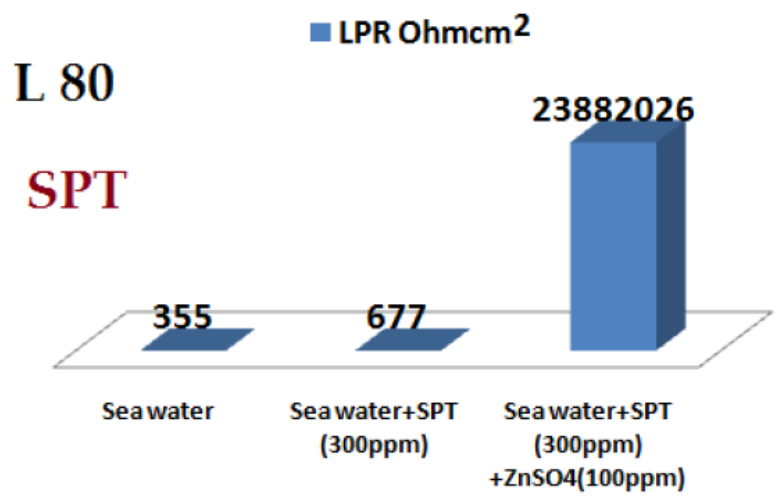

Figure 5. Comparison of LPR values.

\section{AC impedance spectra}

The AC impedance spectra (Nyquist plots, Bode plots) of L80 alloy immersed in various test solutions are shown in Figs. 6 to 11. The corrosion parameters are given in Table 4. It is observed from Table 4 that, when SPT is added to sea water, the corrosion resistance of L80 alloy increases. This is revealed by the fact that there is an increase in $R_{t}$ value, impedance value and decrease in $C_{d l}$ value.

Table 4. Corrosion parameters of L80 alloy immersed in sea water, in the absence and presence of SPT and Zinc sulphate $\left(\mathrm{ZnSO}_{4} \cdot 7 \mathrm{H}_{2} \mathrm{O}\right)$, obtained by AC impedance spectra.

\begin{tabular}{|l|c|c|c|c|}
\hline System & $\begin{array}{c}\text { Rt } \\
\text { Ohm cm }\end{array}$ & $\begin{array}{c}\text { Cdl } \\
\text { F/cm }\end{array}$ & $\begin{array}{c}\text { Impedance } \\
\text { log } \\
\text { (z/ohm) }\end{array}$ & $\begin{array}{c}\text { Phase angle } \\
\text { degree }\end{array}$ \\
\hline Sea water & 5.026 & $0.010 \times 10^{-4}$ & 0.9149 & 22.03 \\
\hline Sea water + SPT (300ppm) & 5.653 & $9.021 \times 10^{-7}$ & 0.9604 & 24.01 \\
\hline $\begin{array}{l}\text { Sea water + SPT (300ppm) + } \\
\mathrm{ZnSO}_{4}(100 \mathrm{ppm})\end{array}$ & 12808933 & $3.982 \times 10^{-13}$ & 7.123 & 96.33 \\
\hline
\end{tabular}

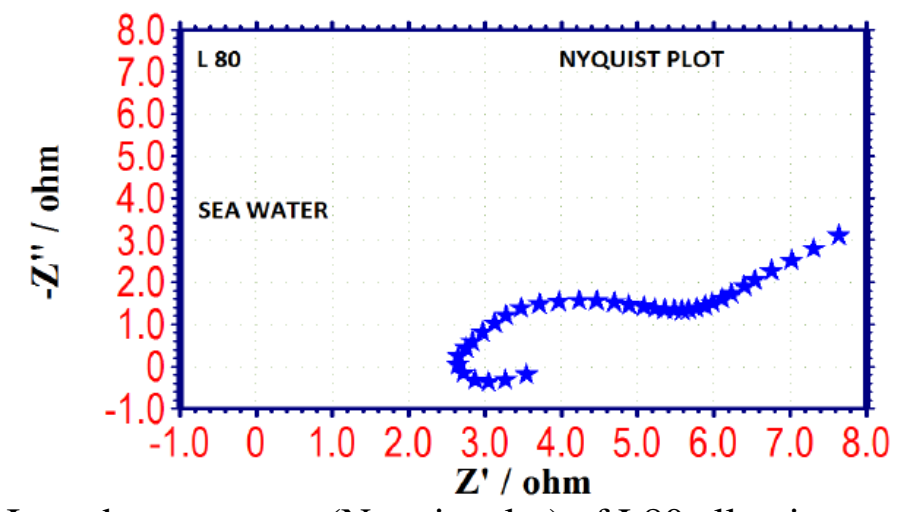

Figure 6. AC Impedance spectra (Nyquist plot) of L80 alloy immersed in sea water. 

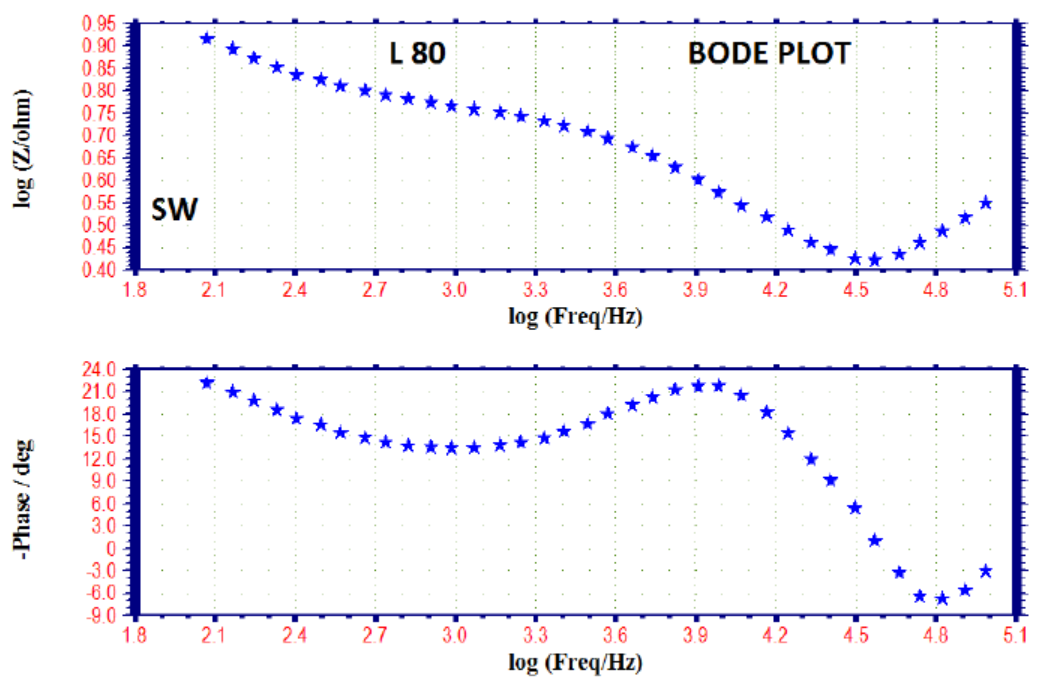

Figure 7. AC Impedance spectra (Bode plot) of L80 alloy immersed in sea water.

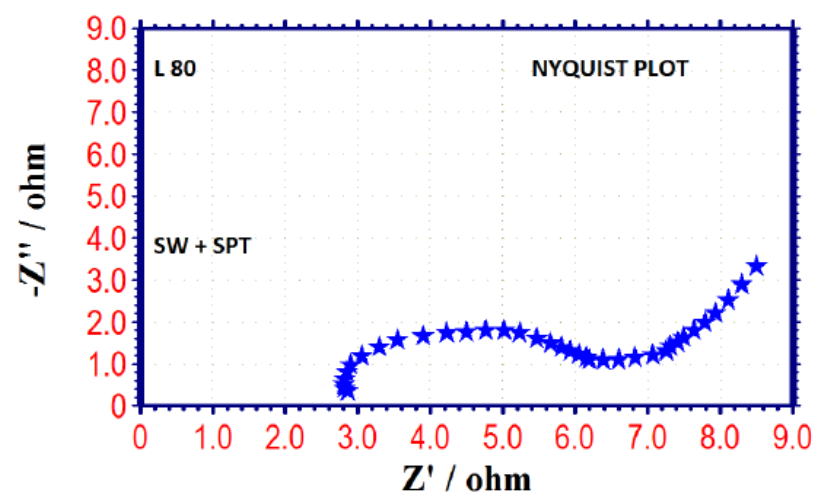

Figure 8. AC Impedance spectra (Nyquist plot) of L80 alloy immersed in sea water + SPT.
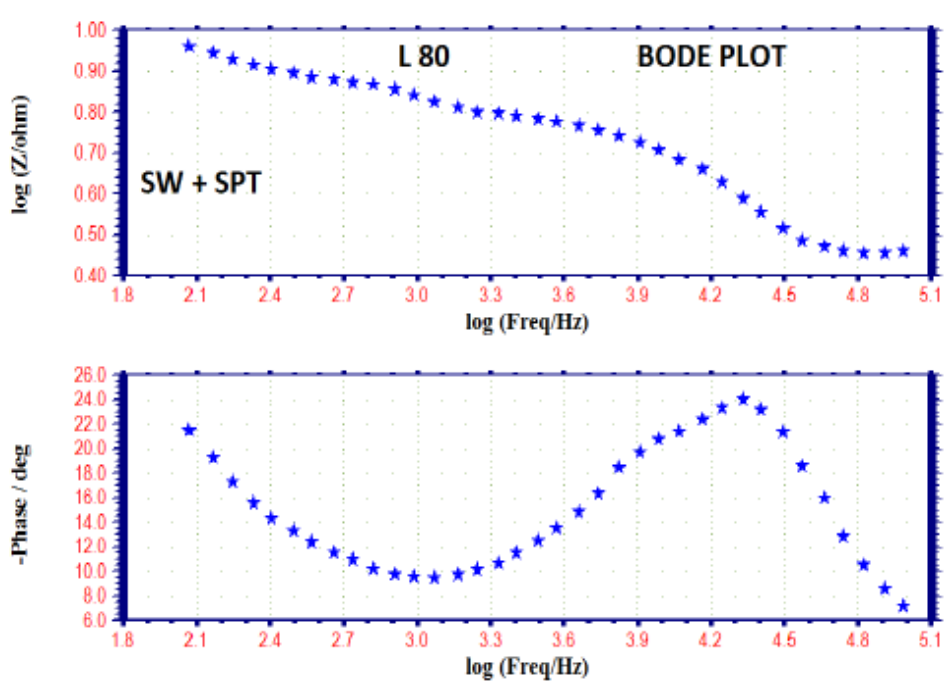

Figure 9. AC Impedance spectra (Bode plot) of L80 alloy immersed in sea water + SPT. 


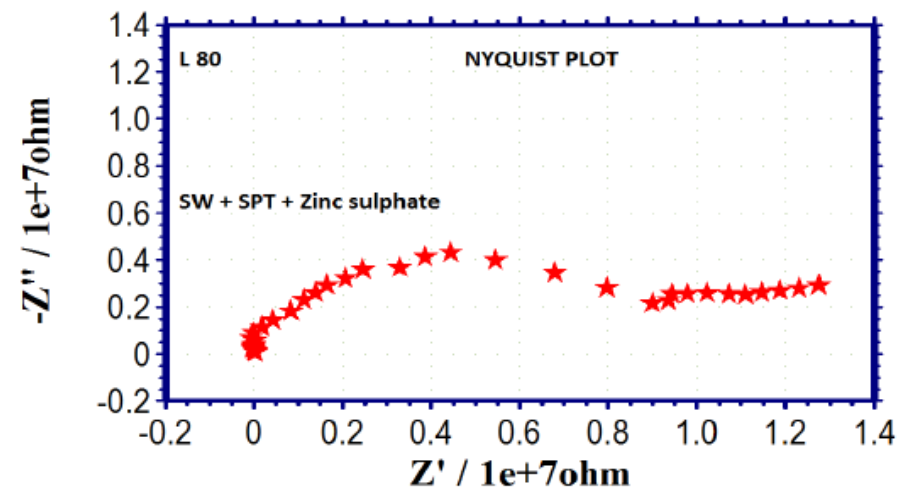

Figure 10. AC Impedance spectra (Nyquist plot) of L80 alloy immersed in sea water + SPT + Zinc Sulphate.
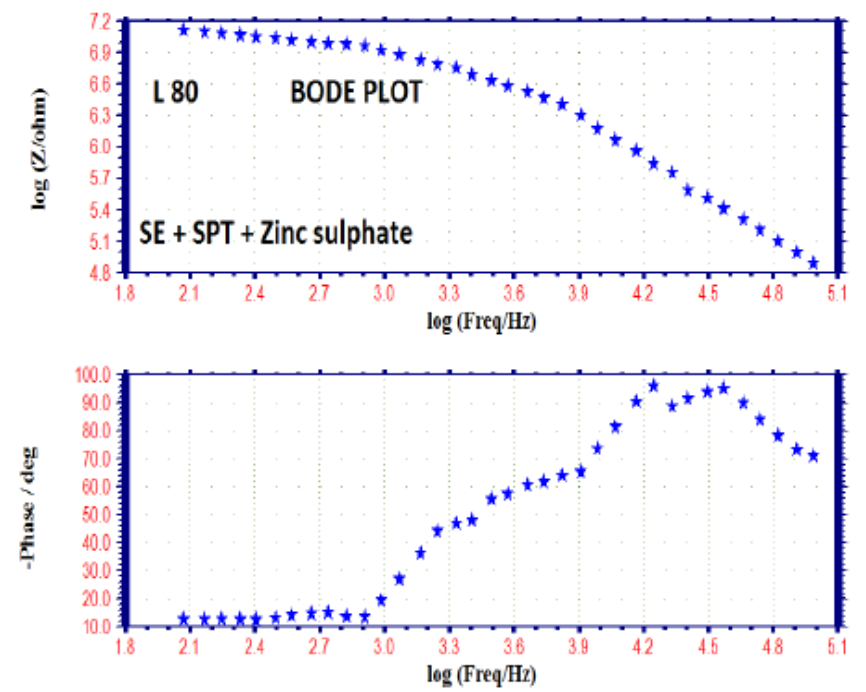

Figure 11. AC Impedance spectra (Bode plot) of mild steel immersed in sea water + $\mathrm{SPT}+\mathrm{ZnSO}_{4}$.

Influence of Zinc sulphate $\left(\mathrm{ZnSO}_{4} .7 \mathrm{H}_{2} \mathrm{O}\right)$

When $\mathrm{ZnSO}_{4} .7 \mathrm{H}_{2} \mathrm{O}$ is added to the above system, the corrosion resistance further increases (Fig. 12). This is revealed by the fact that there is an increase in $R_{t}$ values and impedance value. There is a decrease in $\mathrm{C}_{\mathrm{dl}}$. Thus, electrochemical studies reveal that the corrosion resistance of L80 alloy in sea water decreases in the following order:

$\mathrm{Sea}$ water $+\mathrm{SPT}+\mathrm{ZnSO}_{4}>$ Sea water $+\mathrm{SPT}>$ Sea water.

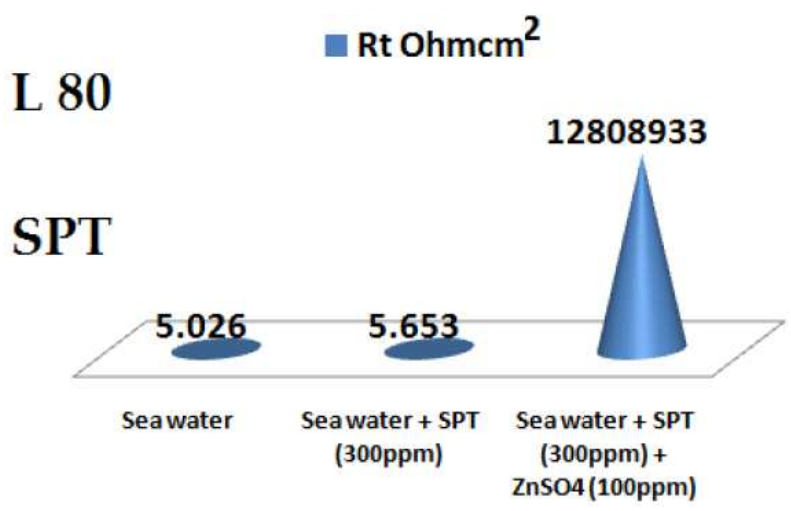

Figure 12. Comparison of Rt value. 


\section{L80 alloy - TSC system}

Polarization study

It is seen from Table 5 that, when TSC is added to sea water, the corrosion resistance of L80 alloy increases. This is revealed by the fact that when TSC is added to sea water, LPR values increases and $\mathrm{I}_{\text {corr }}$ value decreases (Figs.13 and 14). There is the formation of a protective film on the metal surface. So, the transfer of electrons from anodic site to cathodic site is restricted. Hence, LPR value increases and, correspondingly, corrosion current value decreases.

Table 5. Corrosion parameters of L80 alloy immersed in sea water, in the absence and presence of TSC and zinc sulphate $\left(\mathrm{ZnSO}_{4} \cdot 7 \mathrm{H}_{2} \mathrm{O}\right)$, obtained by Polarization study.

\begin{tabular}{|c|c|c|c|c|c|}
\hline System & $\begin{array}{c}\text { Ecorr }_{\text {c }} \\
\mathbf{m V} \\
\text { SCE }\end{array}$ & $\begin{array}{c}\mathbf{b}_{c} \\
\text { mV/decade }\end{array}$ & $\begin{array}{c}\mathbf{b}_{\mathbf{a}} \\
\text { mV/decade }\end{array}$ & $\begin{array}{c}\text { LPR } \\
\text { Ohm cm } \text { cm }^{2}\end{array}$ & $\begin{array}{c}\mathbf{I}_{\text {corr }} \\
\mathrm{A} / \mathrm{cm}^{2}\end{array}$ \\
\hline Sea water & -830 & 161 & 221 & 355 & $1.138 \times 10-4$ \\
\hline $\begin{array}{l}\text { Sea water + TSC (300 } \\
\text { ppm) }\end{array}$ & -761 & 165 & 232 & 391 & $1.076 \times 10-4$ \\
\hline $\begin{array}{l}\text { Sea water + TSC (300 } \\
\text { ppm })+\mathrm{ZnSO}_{4}(100 \mathrm{ppm})\end{array}$ & -704 & 146 & 209 & 465 & $8.044 \times 10-5$ \\
\hline
\end{tabular}

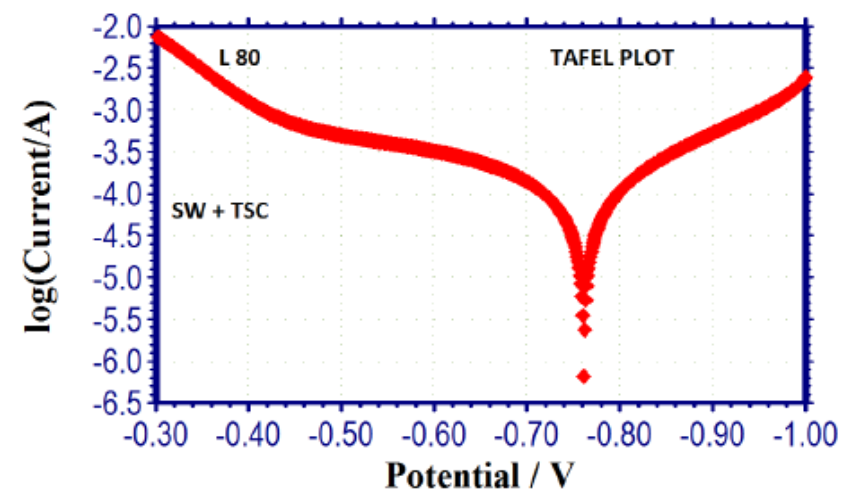

Figure 13. Polarization curve of L80 alloy immersed in sea water + TSC.

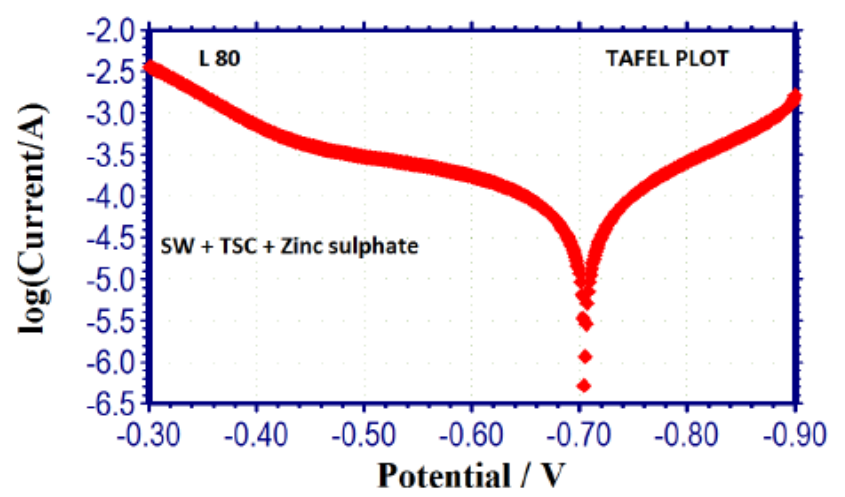

Figure 14. Polarization curve of L80 alloy immersed in sea water + TSC + zinc sulphate.

Influence of Zinc sulphate $\left(\mathrm{ZnSO}_{4} \cdot 7 \mathrm{H}_{2} \mathrm{O}\right)$

When $\mathrm{ZnSO}_{4} .7 \mathrm{H}_{2} \mathrm{O}$ is added to the above system, LPR value increases tremendously (Fig.15) and $\mathrm{I}_{\text {corr }}$ decreases very much. This indicates that, in the 
presence of $\quad \mathrm{SPT}-\mathrm{ZnSO}_{4} \cdot 7 \mathrm{H}_{2} \mathrm{O}$ system, the corrosion resistance of $\mathrm{L} 80$ alloy in sea water increases to a great extent.

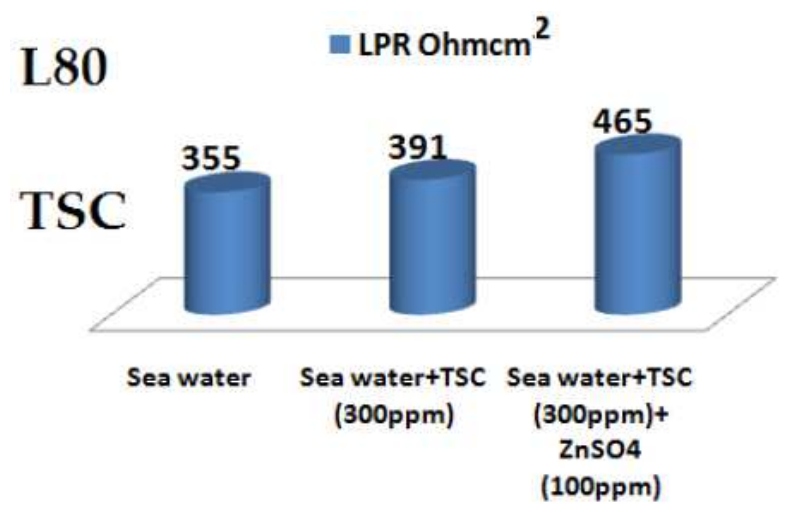

Figure 15. Comparison of LPR values.

\section{AC impedance spectra}

The AC impedance spectra (Nyquist plots, Bode plots) of L80 alloy immersed in various test solutions are shown in Figs. 16 to 19. The corrosion parameters are given in Table 6. It is observed from Table 6 that, when TSC is added to sea water, the corrosion resistance of L80 alloy increases. This is revealed by the fact that there is an increase in $R_{t}$ value and impedance value and a decrease in $C_{d l}$ value.

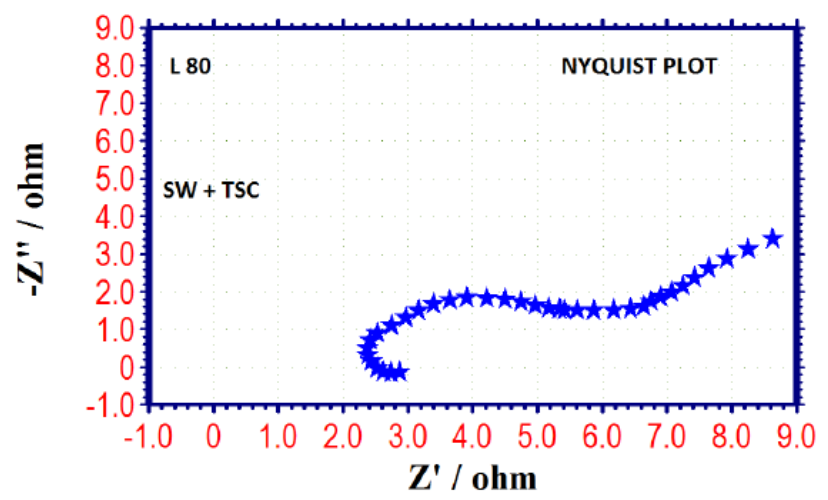

Figure 16. AC Impedance spectra (Nyquist plot) of L80 alloy immersed in sea water + TSC.

Table 6. Corrosion parameters of L80 alloy immersed in sea water, in the absence and presence of TSC and Zinc sulphate $\left(\mathrm{ZnSO}_{4} .7 \mathrm{H}_{2} \mathrm{O}\right)$, obtained by AC impedance spectra.

\begin{tabular}{|l|l|l|l|l|}
\hline System & $\begin{array}{l}\text { Rt } \\
\text { Ohm } \mathbf{~ c m}^{2}\end{array}$ & $\begin{array}{l}\text { Cdl } \\
\text { F/cm }\end{array}$ & $\begin{array}{l}\text { Impedance } \\
\mathbf{l o g}(\mathbf{z} / \mathbf{o h m})\end{array}$ & $\begin{array}{l}\text { Phase } \\
\text { angle } \\
\text { degree }\end{array}$ \\
\hline Sea water & 5.026 & $0.010 \times 10^{-4}$ & 0.9149 & 22.03 \\
\hline Sea water + TSC (300 ppm) & 6.282 & $0.022 \times 10^{-4}$ & 0.9671 & 26.22 \\
\hline $\begin{array}{l}\text { Sea water + TSC (300 ppm) } \\
+\mathrm{ZnSO}_{4}(100 \mathrm{ppm})\end{array}$ & 7.077 & $7.206 \times 10^{-7}$ & 1.021 & 28.84 \\
\hline
\end{tabular}



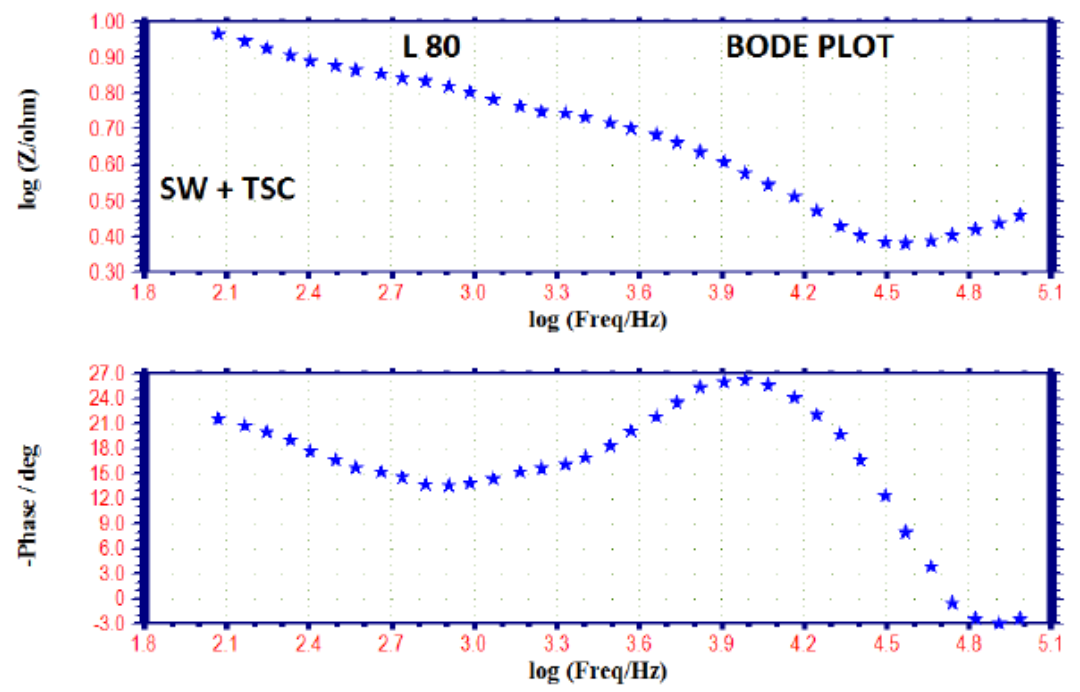

Figure 17. AC Impedance spectra (Bode plot) of L80 alloy immersed in sea water + TSC.

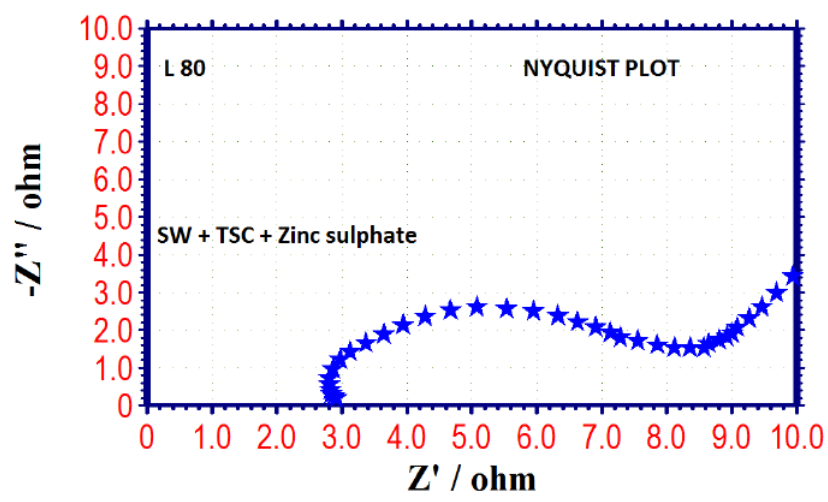

Figure 18. AC Impedance spectra (Nyquist plot) of L80 alloy immersed in sea water + $\mathrm{TSC}+\mathrm{ZnSO}_{4}$
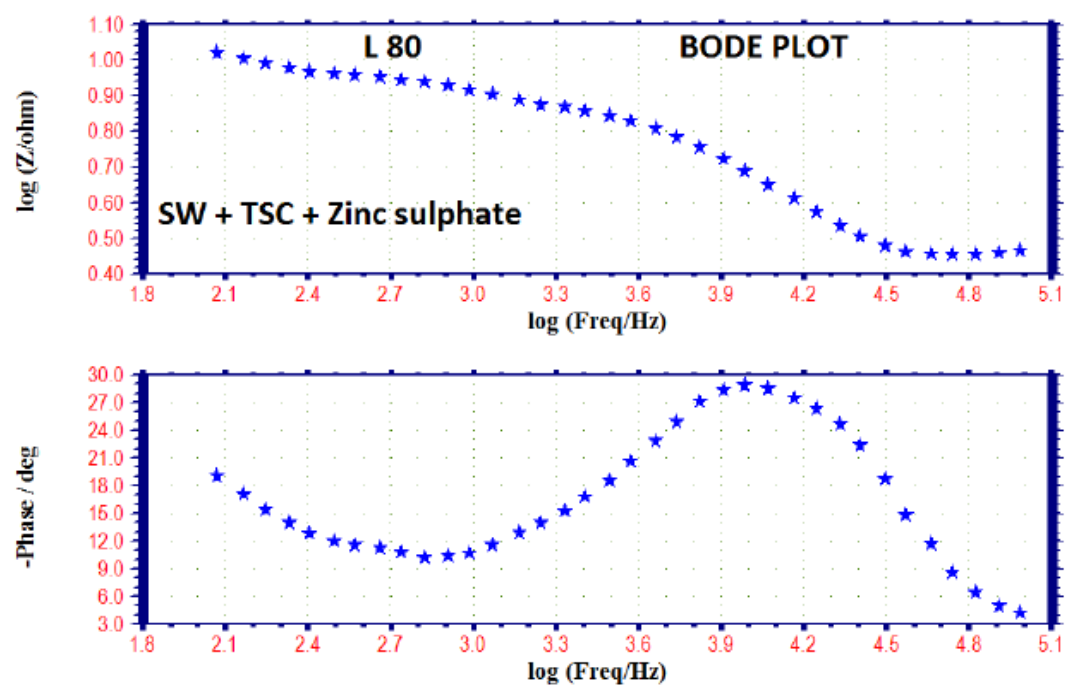

Figure 19. AC Impedance spectra (Bode plot) of L80 alloy immersed in sea water + $\mathrm{TSC}+\mathrm{ZnSO}_{4}$. 
Influence of Zinc sulphate $\left(\mathrm{ZnSO}_{4} .7 \mathrm{H}_{2} \mathrm{O}\right)$

When $\mathrm{ZnSO}_{4} .7 \mathrm{H}_{2} \mathrm{O}$ was added to the above system, the corrosion resistance further increased. This is revealed by the fact that there is an increase in $\mathrm{R}_{\mathrm{t}}$ values (Fig. 20) and impedance value. There is a decrease in $\mathrm{C}_{\mathrm{dl}}$. Thus, electrochemical studies [19-28] reveal that the corrosion resistance of L80 alloy in sea water decreases in the following order:

$\mathrm{Sea}$ water $+\mathrm{TSC}+\mathrm{ZnSO}_{4}>\mathrm{Sea}$ water $+\mathrm{TSC}>\mathrm{Sea}$ water

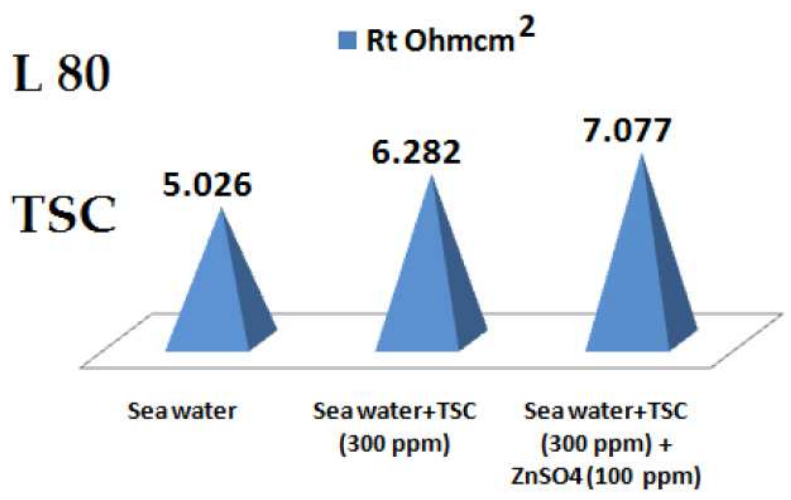

Figure 20. Comparison of $\mathrm{R}_{\mathrm{t}}$ values.

\section{Conclusion}

The corrosion resistance of L80 alloy in sea water, in the absence and presence of sodium potassium tartate (SPT), trisodium citrate (TSC) and zinc sulphate $\left(\mathrm{ZnSO}_{4} \cdot 7 \mathrm{H}_{2} \mathrm{O}\right)$, has been evaluated by electrochemical studies, such as polarization study and AC impedance spectra. The study led to the following conclusions:

L80 alloy - SPT system

Electrochemical studies revealed that the corrosion resistance of L80 alloy in sea water decreases in the following order:

$$
\text { Sea water }+\mathrm{SPT}+\mathrm{ZnSO}_{4}>\text { Sea water }+\mathrm{SPT}>\text { Sea water }
$$

L80 alloy - TSC system

Electrochemical studies revealed that the corrosion resistance of L80 alloy in sea water decreases in the following order:

$$
\text { Sea water }+\mathrm{TSC}+\mathrm{ZnSO}_{4}>\text { Sea water }+\mathrm{TSC}>\text { Sea water }
$$

Addition of Zinc sulphate improves the corrosion resistance of the TSC and SPT systems.

This study also led to the conclusion that the SPT-Zinc system offers better corrosion resistance than the TSC-Zinc system.

\section{Acknowledgements}

The authors are thankful to their respective managements for their help and encouragements. Special thanks are due to the Congregation of The Immaculate 
Conception (CIC), Rev. Sr. Gnana Sundari, Provincial, Madurai Province of CIC, Rev. Sr. M Margaret Inbaseeli, the Secretary and Rev. Sr. Mary Pramila Shanthi, the Principal, St Antony`s College of Arts and Science for Women, Dindigul-624005, India.

\section{References}

1. Duxbury AC, Byrne RH, et al. Encyclopaedia Britannica. Available from: https: // www. britannica. com/ science/ seawater.

2. Genevieve (Genny) Aderson. Seawater Composition. Marine Science. Available

from:http://www.marinebio.net/marinescience/02ocean/swcomposition.htm.2 $003 ; 2.1 .1$.

3. Osman MM. Inhibition of aluminium-brass in $3.5 \% \mathrm{NaCl}$ solution and sea water. Mater Chem Phys. 2001; 71:12-16.

4. Berchmans LJ, Iyer SV, Sivan V, et al. 1,2,4,5 tetrazo spiro $(5,4)$ decane-3 thione as a corrosion inhibitor for arsenical aluminium brass in $3.5 \% \mathrm{NaCl}$ solution. Anti-Corros Methods Mater. 2001;48: 376-381.

5. Aramaki K. Cerium (III) chloride and sodium octylthiopropionate as an effective inhibitor mixture for zinc corrosion. Corros Sci. 2002;44:13611374.

6. Taha KK, Muhideen A. Characterization of anti-corrosion triazole film. J Sci Tech. 2009;10: 92-99.

7. Aljinovic LJ, Gudic S, Smith M. Inhibition of CuNi10Fe in sea water by sodium-diethyl-dithiocarbamate: an electrochemical and analytical study. J Appl Electrochem. 2000;30: 973-979.

8. Dafali A, Hammouti B, Aouniti A, et al. 2-Mercapto-1-methylimidazole as corrosion inhibitor of copper in aerated $3 \% \mathrm{NaCl}$ solution. Annales Chimie Sci Matériaux. 2000;25: 437-446.

9. Majumdar I, D’Souza F, Bhosle NB. Microbial exopolysaccharides: Effect on corrosion and partial chemical characterization. J Ind Inst Sci. 1999;79: 539-550.

10. Rajendran S, Apparao BV, Palaniswamy N. Corrosion inhibition by phosphonic acid - Zn systems for mild steel in chloride medium. Anti-Corros Methods Mater. 2000; 47: 359-365.

11. Dubey RS, Potdar Y. Corrosion inhibition of 304 stainless steel in sodium chloride by ciprofloxacin and norfloxacin. Ind J Chem Tech. 2009;16: 334338.

12. Aramide FO. Corrosion inhibition of AISI/SAE Steel in a marine environment. Leonardo J Sci. 2009; 15: 47-52.

13. Laamari MR, Derja A, Benzakourm J, et al. Calcium monofluorophosphate: a new class of corrosion inhibitors in $\mathrm{NaCl}$ medium. J Electroanal Chem. 2004;569: 1-6.

14. Ozyilmaz AT, Erbil M, Yazici B. The influence of polyaniline (PANI) top coat on corrosion behavior of nickel plated copper. Appl Surf Sci. 2005; 252: 2092-2100. 
15. Aballe A, Bethencourt M, Botana FJ, et al. Electrochemical noise applied to the study of the inhibition effect of $\mathrm{CeCl}_{3}$ on the corrosion behaviour of AlMg alloy AA5083 in sea water. Electrochim Acta. 2002;47:1415-1422.

16. Aramaki K. Cerium (III) chloride and sodium octylthiopropionate as an effective inhibitor mixture for zinc corrosion. Corros Sci. 2002;44:13611374.

17. Rani PD, Selvaraj S. Inhibitive action of Vitis vinifera (Grape) on copper and brass in natural sea water environment. Rasayan J Chem. 2010;3: 473-482.

18. Deepa Rani P, Selvaraj S. Emblica Officinalis (OMLA) leaves extract as corrosion inhibitor for copper and its alloy $(\mathrm{Cu}-27 \mathrm{Zn})$ in natural sea water. Arch Appl Sci Res. 2010;2: 140-150.

19. Rajendran S, Devi MK, Regis APP, et al. Electroplating using environmental friendly garlic extract, A case study. Zastita Materijala. 2009; 50: 131-140.

20. Rajendran S, Chitradevi P, Johnmary S, et al. Corrosion behaviour of SS 316 $\mathrm{L}$ in artificial saliva in presence of electral. Zastita Materijala. 2010;51: 149158.

21. Rajendran S, Agasta M, Devi RB, et al.Corrosion inhibition by an aqueous extract of Henna leaves (Lawsonia Inermis L). Zastita Materijala. 2009;50: 77-84.

22. Mary ACC, Rajendran S, Jeyasundari J. Influence of Coffee on the corrosion resistance of SS $316 \mathrm{~L}$, Ni-Ti alloy and thermoactive alloy in artificial saliva. Eur Chem Bull. 2017;6: 232-237.

23. Sribharathy V, Rajendran S, Rengan $\mathrm{P}$, et al. Corrosion Inhibition By An Aqueous Extract Of Aleovera (L) Burm F.(Liliaceae), Eur Chem Bull. 2013;2: 471-476.

24. Epshiba R, Regis APP, Rajendran S. Inhibition Of Corrosion Of Carbon Steel In A Well Water By Sodium Molybdate-Zn 2 System. Int J Nano Corros Sci Eng. 2014;1: 1-11.

25. Kavitha N, Manjula P. Corrosion Inhibition of Water Hyacinth Leaves, $\mathrm{Zn}^{2+}$ and TSC on Mild Steel in neutral aqueous medium. Int J Nano Corros Sci Eng. 2014;1: 31 - 38.

26. Nagalakshmi R, Nagarajan L, Joseph Rathish R et al. Corrosion Resistance Of SS3161 In Artificial Urine In Presence Of D-Glucose. Int J Nano Corros Sci Eng. 2014;1: 39- 49.

27. Angelin Thangakani J, Rajendran S, Sathiabama J, et al. Inhibition Of Corrosion Of Carbon Steel In Aqueous Solution Containing Low Chloride Ion By Glycine - Zn ${ }^{2+}$ System. Int J Nano Corros Sci Eng. 2014;1:50 - 62.

28. Gowri S, Sathiyabama J, Rajendran S, et al. Tryptophan as corrosion inhibitor for carbon steel in sea water. J Chem, Biol Phys Sci. 2012; 2: 2223. 